\title{
Correction to: Thermodynamic model and Raman spectra of $\mathrm{MgO}-\mathrm{P}_{2} \mathrm{O}_{5}$ glasses
}

\author{
Branislav Hruška ${ }^{1}$ Rajesh Dagupati ${ }^{1}$ Mária Chromčíková ${ }^{2,3}$ - Aleksandra Nowicka ${ }^{1}$ Jan Macháček ${ }^{4}$. \\ Marek Liška ${ }^{2,3} \cdot$ Francisco Munoz ${ }^{5}$
}

Published online: 14 September 2020

(c) The Authors(s) 2020

\section{Correction to: Journal of Thermal Analysis and Calorimetry https://doi.org/10.1007/s10973-020-10033-1}

The article "Thermodynamic model and Raman spectra of $\mathrm{MgO}-\mathrm{P}_{2} \mathrm{O}_{5}$ glasses", written by Branislav Hruška, Rajesh Dagupati, Mária Chromč́́ková, Aleksandra Nowicka, Jan Macháček, Marek Liška and Francisco Munoz., was originally published electronically on the publisher's internet portal on 20 July 2020 without open access. With the author(s)' decision to opt for Open Choice the copyright of the article changed on 24 August 2020 to (C) The Author(s) 2020 and the article is forthwith distributed under a Creative Commons Attribution 4.0 International License, which permits use, sharing, adaptation, distribution and reproduction in any medium or format, as long as you give appropriate credit to the original author(s) and the source, provide a link to the Creative Commons licence, and indicate if changes were made. The images or other third party material in this article are included in the article's Creative Commons licence, unless indicated otherwise in a credit line to the material. If material is not included in the article's Creative Commons

The original article can be found online at https://doi.org/10.1007/ s10973-020-10033-1.

Branislav Hruška

branislav.hruska@tnuni.sk

1 FunGlass, Alexander Dubček University of Trenčín, Študentská 2, Trenčín 911 50, Slovakia

2 VILA - Joined Glass Centre of the IIC SAS, TnUAD, FChPT STU, Študentská 2, Trenčín 911 50, Slovakia

3 Institute of Inorganic Chemistry of Slovak Academy of Sciences, Dúbravská cesta 9, Bratislava 845 36, Slovakia

4 Faculty of Chemical Technology, University of Chemistry and Technology, Prague, Technická 5, Prague 166 28, Czech Republic

5 Institute of Ceramics and Glass (CSIC), Kelsen 5, 28049 Madrid, Spain licence and your intended use is not permitted by statutory regulation or exceeds the permitted use, you will need to obtain permission directly from the copyright holder. To view a copy of this licence, visit http://creativecommons .org/licenses/by/4.0.

The original article has been corrected.

Open Access This article is licensed under a Creative Commons Attribution 4.0 International License, which permits use, sharing, adaptation, distribution and reproduction in any medium or format, as long as you give appropriate credit to the original author(s) and the source, provide a link to the Creative Commons licence, and indicate if changes were made. The images or other third party material in this article are included in the article's Creative Commons licence, unless indicated otherwise in a credit line to the material. If material is not included in the article's Creative Commons licence and your intended use is not permitted by statutory regulation or exceeds the permitted use, you will need to obtain permission directly from the copyright holder. To view a copy of this licence, visit http://creativecommons.org/licenses/by/4.0/.

Publisher's Note Springer Nature remains neutral with regard to jurisdictional claims in published maps and institutional affiliations. 